\title{
Actinomycosis of the scalp or tuberculosis? A clinical conundrum!
}

\author{
Gabriel Rodrigues, ${ }^{1}{ }^{1}$ Sunitha Carnelio $^{2}$
}

${ }^{1}$ General Surgery, Kasturba Medical College, Manipal Academy of Higher Education, Manipal, Karnataka, India ${ }^{2}$ Oral \& Maxillofacial Pathology, Manipal College of Dental Sciences, Manipal Academy of Higher Education, Manipal, Karnataka, India

\section{Correspondence to} Professor Gabriel Rodrigues, gabyrodricks@gmail.com

Accepted 8 May 2019

\section{Check for updates}

(C) BMJ Publishing Group Limited 2019. No commercial re-use. See rights and permissions. Published by BMJ.

To cite: Rodrigues $\mathrm{G}$, Carnelio S. BMJ Case Rep 2019;12:e230563. doi:10.1136/bcr-2019230563

\section{DESCRIPTION}

A 36-year-old man who had previously sustained multiple bruises on his scalp due to a road traffic accident that had healed spontaneously, reported with multiple, painless, greenish pus draining sinuses at the same site since 8 months. There were no systemic symptoms. Local examination confirmed the same with sinuses having pouting granulation tissue and no bony tenderness or fractures (figure 1A). Occipital non-tender lymphadenopathy was present.

Tuberculous osteomyelitis was suspected and pus sent for Gram stain, culture and GeneXpert, but was not contributory. Mantoux test was also negative. Skull radiograph showed a thickened parietal vault and intact inner table, but multiple defects in the outer table suggestive of chronic osteomyelitis. A punch biopsy from the granulation tissue done showed foci of sulfur granules comprising of filamentous basophilic radiating fungal-like structures in the dermis surrounded by acute and chronic inflammatory cells, namely, neutrophils, plasma cells and foamy macrophages intervened with fibroblasts representing actinomyces (figure 1B). Fine needle aspiration cytology of the occipital lymph nodes was inconclusive.

Actinomycosis is a rare, chronic bacterial anaerobic infectious disease caused by Actinomyces species (ray fungus), which is ubiquitous and occurs in soil and in the microbiota of animals and humans. ${ }^{1}$ It

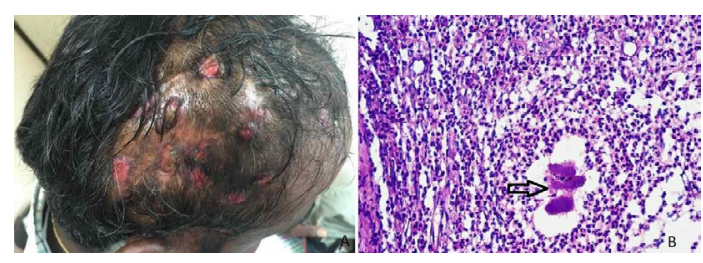

Figure 1 (A) Multiple sinuses of the scalp; (B) Photomicrograph showing actinomyces (black arrow), $H \& E \times 40$.

\section{Learning points}

- Actinomycosis is a granulomatous bacterial infection.

- It can mimic tuberculosis and a biopsy from the sinuses is conclusive.

- Penicillin is the drug of choice, but surgical excision of the sinuses might be required.

is characterised by contiguous spread, suppurative and granulomatous inflammation, and formation of multiple abscesses and sinus tracts that may discharge sulfur granules. ${ }^{2}$ Common clinical forms are cervicofacial, thoracic and abdominal and in women, pelvic actinomycosis. ${ }^{3}$ Tuberculous osteomyelitis mimics actinomycosis, causing a diagnostic dilemma and only a biopsy can confirm the diagnosis. The patient was started on penicillin $G$ and sinus tracts were excised. At a follow-up visit, 1 month later, the sinuses have healed well but with fibrosis and patchy alopecia.

Contributors GR: concept, planning, literature search, manuscript writing, editing and final approval. SC: diagnostics, literature search, manuscript writing, editing and final approval.

Funding The authors have not declared a specific grant for this research from any funding agency in the public, commercial or not-for-profit sectors.

Competing interests None declared.

Patient consent for publication Obtained.

Provenance and peer review Not commissioned; externally peer reviewed.

\section{REFERENCES}

1 Akhtar M, Zade MP, Shahane PL, et al. Scalp actinomycosis presenting as soft tissue tumour: A case report with literature review. Int J Surg Case Rep 2015;16:99-101.

2 Kalioras V, Thanos L, Mylona S, et al. Scalp actinomycosis mimicking soft tissue mass. Dentomaxillofac Radiol 2006;35:117-8.

3 Hegde V, Puthran N, Mahesha S, et al. A rare and an unusually delayed presentation of orbital actinomycosis following avulsion injury of the scalp. Indian J Ophthalmol 2010;58:238-40.
Copyright 2019 BMJ Publishing Group. All rights reserved. For permission to reuse any of this content visit https://www.bmj.com/company/products-services/rights-and-licensing/permissions/

BMJ Case Report Fellows may re-use this article for personal use and teaching without any further permission.

Become a Fellow of BMJ Case Reports today and you can:

- Submit as many cases as you like

- Enjoy fast sympathetic peer review and rapid publication of accepted articles

- Access all the published articles

- Re-use any of the published material for personal use and teaching without further permission

For information on Institutional Fellowships contact consortiasales@bmjgroup.com

Visit casereports.bmj.com for more articles like this and to become a Fellow 